\title{
Respiratory Muscle Strength Evaluation in Healthy Adult and Elderly Women
}

\section{-Respiratory Muscle Strength Assessment in Adult and Elderly}

\author{
Maria Clara de Souza Pereira Gama Maciel, Cássio Daniel Araújo da Silva*, \\ Fernanda Figueiroa Sanchez, Jamilly Rebouças Demosthenes Marques, Pablo Costa Cortez, \\ Camila Miriam Suemi Sato Barros do Amaral, Naylla Morais de Souza, Roberta Lins Gonçalves
}

Federal University of Amazonas-UFAM, Manaus, Brazil

Email: *cd.danielsilva@gmail.com

How to cite this paper: Maciel, M.C.S.P.G., da Silva, C.D.A., Sanchez, F.F., Marques, J.R.D., Cortez, P.C., do Amaral, C.M.S.S.B., de Souza, N.M. and Gonçalves, R.L. (2018) Respiratory Muscle Strength Evaluation in Healthy Adult and Elderly Women. Health, 10, 1031-1036.

https://doi.org/10.4236/health.2018.108077

Received: June 8, 2018

Accepted: July 30, 2018

Published: August 3, 2018

Copyright $\odot 2018$ by authors and Scientific Research Publishing Inc. This work is licensed under the Creative Commons Attribution-NonCommercial International License (CC BY-NC 4.0). http://creativecommons.org/licenses/by-nc/4.0/ cc) (i) (8) Open Access

\begin{abstract}
Measurement of respiratory muscle strength is performed through static measurements of maximal respiratory pressures and is an important tool for determining the existence and prognosis of neuromuscular and pulmonary disorders, such as weakness or fatigue of this musculature. Objectives: To evaluate and compare respiratory muscle strength among healthy adult and elderly women. Methods: A total of 163 healthy women were recruited through convenience sampling at the family centers of the city of Manaus (AM, Brazil), divided into two groups: adult women (age 20 - 59 years) and elderly women (over 60 years of age). The evaluation was performed by Manovacuometry, in order to measure the maximum inspiratory pressure (MIP) and maximum expiratory pressure (MEP). For statistical analysis we used the Student's $\mathrm{T}$ test, considering significant $\mathrm{p}$ value $\leq 0.05$. Results: The final sample consisted of 116 adult women and 47 elderly women. The mean age in the group of women between $20-59$ years was $44.5 \pm 12$ and the elderly group was $65 \pm 6.6$. MIP values in adult women were significantly higher when compared to the elderly $\left(-108 \pm 5.3 \mathrm{cmH}_{2} \mathrm{O} \times-79.5 \pm 4 \mathrm{cmH}_{2} \mathrm{O}, \mathrm{p}=\right.$ 0.0014 , respectively). The same behavior was observed in the evaluation of MEP $\left(87.1 \pm 2.9 \mathrm{cmH}_{2} \mathrm{O}\right.$ in adults and $69.8 \pm 3.5 \mathrm{cmH}_{2} \mathrm{O}$ in the elderly; $\mathrm{p}=$ 0.0008). Conclusion: The results indicate that inspiratory and expiratory muscle strength is lower in older women, suggesting that the aging process tends to interfere with those muscles, resulting in altered respiratory system function.
\end{abstract}

\section{Keywords}

Muscular Strength, Evaluation, Respiratory Muscles, Aging 


\section{Introduction}

The search for biological parameters related to the natural aging process has provided improved living conditions and knowledge about health for the elderly population, since the increase in life expectancy reverberates in the exponential increase of this population and constitutes a challenge for social assistance and public health [1] [2] [3]. In addition, the physiological condition of aging carries with it the almost invariable reduction of demands and global metabolic resources, with negative impact on the musculoskeletal and respiratory systems, among others [4].

Thus, continuous monitoring of pulmonary function may be useful in determining the consequences, extension and progression of various pathological conditions, mainly neuromuscular disorders. Measurement of maximum respiratory pressures and vital capacity are among the main methods for this evaluation [5]. In previously healthy individuals, this measurement quantifies and classifies muscle strength according to the parameters of normality, since it contributes to the understanding of the behavior of the respiratory system, besides allowing comparing the data obtained from the healthy population with the data of individuals who have some type of involvement in muscular strength, analyzing the differences found [6].

The maximum respiratory pressures are defined as the maximum static pressure that is generated by the mouth after a maximal inspiratory or expiratory incursion, respectively, MIP and MEP [7] [8]. The determining factors for this evaluation are the gender, age, height, weight, muscular work capacity or physical fitness, lung volume at which the measurements were made, and the corresponding value of the elastic recoil pressure of the respiratory system, smoking, educational level and motivation of the individual [9]. In healthy elderly, on the other hand, the main functional alterations of the respiratory apparatus include the reduction of chest wall complacency, respiratory muscle strength, vital capacity and arterial oxygen pressure [10]. Thus, the present study aimed to evaluate respiratory muscle strength in healthy adult and elderly women, considering the progression of age.

\section{Methods}

This is a cross-sectional study, approved by the Research Ethics Committee of the Federal University of Amazonas (CEP/UFAM), whose initial sample consisted of 169 healthy volunteers, participants of the Family Living Centers and the academic community of the Federal University of Amazonas - UFAM. The volunteers were selected according to the following inclusion criteria: Being female, presenting BMI between 18 and $29.5 \mathrm{~kg} / \mathrm{m}^{2}$ and having no history of smoking or chronic disease. Individuals with a history of recent respiratory or cardiovascular disease were excluded, as well as those with any neuromuscular disease that prevented the tests from being performed. Thus, the final sample consisted of 163 healthy women aged 20 - 88 years divided into two groups: 
adult women (age 20 - 59 years) and elderly women (aged over 60 years). For didactic purposes, we considered healthy volunteers without clinical follow-up at the time of data collection, and only the regular participants of the health promotion programs of the coexistence centers were invited.

Personal and previous history data were collected through directed form, and anthropometric measurements performed by balance/analogicstadiometer. Respiratory muscle strength was measured by Measurement of Maximum Inspiratory Pressure (MIP) and Maximum Expiratory Pressure (MEP) with an analogicmanovacuometer (trademark Wika $\odot$ ) following the guidelines of the American Thoracic Society [11]. Statistical analysis was performed using Student's T-Test considering significant $\mathrm{p} \leq 0.05$, through software " $\mathrm{R}$ " version 3.2.

\section{Results}

The final sample consisted of 116 adult women and 47 elderly women. Table 1 shows the anthropometric data of the studied sample described with mean and standard deviation. We can observe that the mean age of adult women was $44.5 \pm 12$ years, and between elderly was $65 \pm 6.6$ years. The mean BMI of adult and elderly women was $26.5 \pm 5.1 \mathrm{~kg} / \mathrm{m}^{2}$ and $27.2 \pm 4.7 \mathrm{~kg} / \mathrm{m}^{2}$, respectively.

Table 2 shows the behavior of MIP and MEP when analyzed in relation to age, where the values evaluated are lower in elderly women, with a value of $\mathrm{p}<$ 0.05 .

When staging the values of maximum respiratory pressures in each age group, it is noted that the inspiratory and expiratory muscle strength in women shows a tendency to decrease progressively in each decade as the age passes (Graph 1 and Graph 2).

\section{Discussion}

The main results of this study show the difference in MIP and MEP values

Table 1. Anthropometric data of the sample studied.

\begin{tabular}{ccccc}
\hline \multirow{2}{*}{ Groups } & AGE (years) & WEIGHT $(\mathrm{kg})$ & HEIGHT $(\mathrm{m})$ & BMI $\left(\mathrm{kg} / \mathrm{m}^{2}\right)$ \\
\cline { 2 - 5 } & $\begin{array}{c}\text { Mean } \pm \text { Standard } \\
\text { Deviation }\end{array}$ & $\begin{array}{c}\text { Mean } \pm \text { Standard } \\
\text { Deviation }\end{array}$ & $\begin{array}{c}\text { Mean } \pm \text { Standard } \\
\text { Deviation }\end{array}$ & $\begin{array}{c}\text { Mean } \pm \text { Standard } \\
\text { Deviation }\end{array}$ \\
\hline Adult Women & $44.5 \pm 12$ & $64.7 \pm 12.9$ & $1.5 \pm 0.07$ & $26.5 \pm 5.1$ \\
Older Women & $65 \pm 6.6$ & $64.3 \pm 11.2$ & $1.5 \pm 0.07$ & $27.2 \pm 4.7$ \\
\hline
\end{tabular}

Table 2. MIP, MEP and $P$-value in adult and elderly groups.

\begin{tabular}{ccc}
\hline & $\mathrm{MIP}\left(\mathrm{cmH}_{2} \mathrm{O}\right)$ & MEP $\left(\mathrm{cmH}_{2} \mathrm{O}\right)$ \\
\cline { 2 - 3 } & Mean \pm Standard Deviation & Mean \pm Standard Deviation \\
\hline Adult Women & $-108 . \pm 5.3$ & $87.1 \pm 2.9$ \\
Older Women & $-79.5 \pm 4$ & $69.8 \pm 3.5$ \\
$P$-Value & 0.0014 & 0.0008 \\
\hline
\end{tabular}




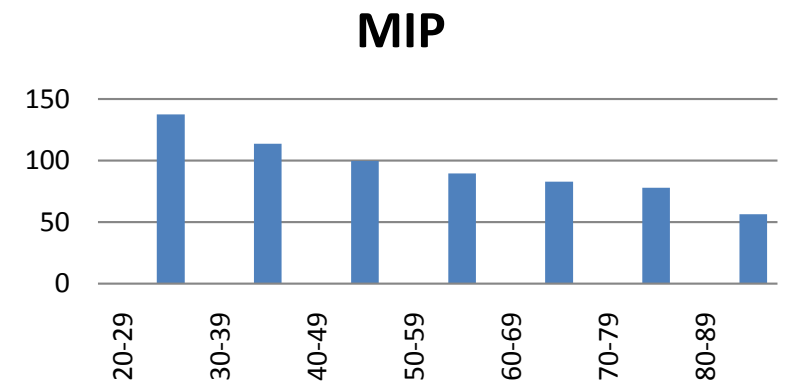

Graph 1. MIP $\times$ age group.

\section{MEP}

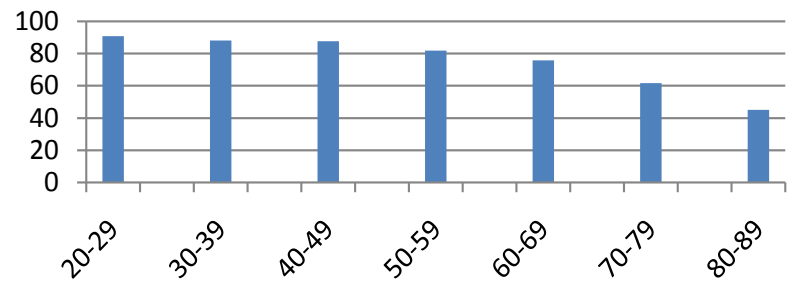

Graph 2. MEP $\times$ age group.

between the groups of adult and elderly women, in addition to the progressive decrease of these variables according to an age group. These reductions in the values of respiratory pressures may be related to the physiological changes of the aging process, such as changes in the composition of the lung tissue and the thoracic cavity, which decrease the mass and the efficiency of the respiratory muscles [12].

Corroborating our findings, Carpenter et al. [13]. conducted a study about MIP in the age group of 47 - 68 years and observed that for each year an increase in age led to a decrease of $0.93 \mathrm{cmH}_{2} \mathrm{O}$ in women. On the other hand, the behavior of these pressures maintains a certain stability until the 55 - 60 years of age and, from then decline markedly in modules. This fact does not prevent the elderly from maintaining their ventilation, but is dependent on an important respiratory protection mechanism: cough [4].

Another study on the subject [14] demonstrated reductions in MIP and MEP between 0.8 and $2.7 \mathrm{cmH}_{2} \mathrm{O}$ per year in the elderly from 65 years, in both sexes, with further decline in men. Furthermore, Tolep et al. [15] found evidence that muscle changes associated with aging affect respiratory muscle function, with a significant reduction of $25 \%$ in diaphragm strength in the elderly compared to young adults [16].

In most studies, however, sex and age are the two most consensually explaining variations in MIP and MEP, being lower in women, and lower in advancing age [9]. It is important to emphasize that good daily habits and regular physical exercise contribute to healthy aging, leading to an improvement in cardiorespiratory capacity, increased strength and resistance to fatigue and psychological 
well-being [10].

As limitations of the present study, we can point out the small $\mathrm{N}$ in the group of elderly women and the absence of digital equipment to verify the measures.

\section{Conclusion}

The results indicate that inspiratory and expiratory muscle strength is lower in older women, suggesting that the aging process tends to interfere with the respiratory muscles. As a consequence, a predisposition of the elderly to decrease the respiratory capacity and increase the chances of fatigue is observed.

\section{Conflicts of Interest}

The authors declare no conflicts of interest regarding the publication of this paper.

\section{References}

[1] Black, L.F. and Hyatt, R.E. (1969) Maximal Respiratory Pressures: Normal Values and Relationship to Age and Sex. The American Review of Respiratory Disease, 99, 696-702.

[2] Neder, J.A., Andreoni, S., Castelo-Filho, A. and Nery, L.E. (1999) Reference Values for Lung Function Tests. I. Static Volumes. Brazilian Journal of Medical and Biological Research, 32, 703-717. https://doi.org/10.1590/S0100-879X1999000600006

[3] Neder, J.A., Andreoni, S., Castelo-Filho, A. and Nery, L.E. (1999) Reference Values for Lung Function Tests. II. Maximal Respiratory Pressures and Voluntary Ventilation. Brazilian Journal of Medical and Biological Research, 32, 719-727. https://doi.org/10.1590/S0100-879X1999000600007

[4] Gonçalves, M.P., Tomaz, C.A.B., Cassiminho, A.L.F. and Dutra, M.F. (2006) Avaliação da força muscular inspiratória e expiratória em idosas praticantes de atividade física e sedentárias. Revista Brasileira de Ciência e Movimento, 14, 37-44.

[5] Fiori Junior, J.F., Paisani, D.M., Franceschini, J., Chiavegato, L.D. and Faresin, S.M. (2004) Pressões respiratórias máximas e capacidade vital: Comparação entre avaliações através de bocal e de máscara facial. Jornal Brasileiro de Pneumologia, 30, 515-520. https://doi.org/10.1590/S1806-37132004000600005

[6] Leal, A.H., Hamasaki, T.A., Jamami, M., Di Lorenzo, V.A.P. and Pessoa, V.B. (2007) Comparação entre valores de força muscular respiratória medidos e previstos por diferentes equações. Fisioterapia e Pesquisa, 14, 25-30.

[7] Costa, D., Gonçalves, H.A., de Lima, L.P., Ike, D., Cancelliero, K.M. and Montebelo, M.I. (2010) New Reference Values for Maximal Respiratory Pressures in the Brazilian Population. Jornal Brasileiro de Pneumologia, 36, 306-312. https://doi.org/10.1590/S1806-37132010000300007

[8] Günther Mangelsdorff, G., Gisella Borzone, T., Alicia Leiva, G., Alejandro Martínez, S. and Carmen Lisboa, B. (2001) Potencia de los músculos inspiratorios en insufiencia cardíaca crónica y en enfermedad pulmonar obtructiva crónica. Revista Médica de Chile, 129, 51-59.

[9] Pessoa, I.M.B.S., Houri Neto, M., Montemezzo, D., Silva, L.A.M., Andrade, A.D. and Parreira, V.F. (2014) Predictive Equations for Respiratory Muscle Strength According to International and Brazilian Guidelines. Brazilian Journal of Physical 
Therapy. https://doi.org/10.1590/bjpt-rbf.2014.0044

[10] Gorzoni, M.L. and E. Russo, M.R. (2002) Envelhecimento respiratório. In Freitas, E.V., Py, L., Neri, A.L., Cançado, F.A.X., Gorzoni, M.L. and Rocha, S.M., Eds., Tratado de Geriatria e Gerontologia, Guanabara Koogan, Rio de Janeiro, 340-343.

[11] American Thoracic Society/European Respiratory Society (2002) ATS/ERS Statement on Respiratory Muscle Testing. American Journal of Respiratory and Critical Care Medicine, 166, 518-624. https://doi.org/10.1164/rccm.166.4.518

[12] Simões, R.P., Deus, A.P.L., Auad, M.A., Dionísio, J., Mazzonetto, M. and Borghi-Silva, A. (2001) Pressões respiratórias máximas em indivíduos saudáveis sedentários de 20 a 89 anos da região central do Estado de São Paulo. Brazilian Journal of Physical Therapy, 14, 60-67. https://doi.org/10.1590/S1413-35552010000100010

[13] Carpenter, M.A., Tockman, M.S., Hutchinson, R.G., Davis, C.E. and Heiss, G. (1999) Demographic and Antropometric Correlates of Maximum Inspiratoy Pressure. The Atherosclerosis Risk in Communities Study. American Journal of Respiratory and Critical Care Medicine, 51, 415-422. https://doi.org/10.1164/ajrccm.159.2.9708076

[14] Enright, P.L., Kronmal, R.A., Manolio, T.A., Schenker, M.B. and Hyatt, R.E. (1994) Respiratory Muscle Strength in the Elderly. Correlates and Reference Values. American Journal of Respiratory and Critical Care Medicine, 149, 430-438. https://doi.org/10.1164/ajrccm.149.2.8306041

[15] Tolep, K., Higgins, N., Muza, S., Griner, G. and Kelsen, S.G. (1995) Comparison of Diaphragm Strength between Healthy Adult Elderly and Young Men. American Journal of Respiratory and Critical Care Medicine, 152, 677-682. https://doi.org/10.1164/ajrccm.152.2.7633725

[16] Simões, L.A., Dias, J.M.D., Marinho, K.C., Pinto, C.L.L.R. and Britto, R.R. (2010) Relationship between Functional Capacity Assessed by Walking Test and Respiratory and Lower Limb Muscle Function in Community-Dwelling Elders. Brazilian Journal of Physical Therapy, 14, 24-30. https://doi.org/10.1590/S1413-35552010000100005 